\title{
THE SOCIAL RECRUITMENT AS A NEW OPPORTUNITY IN THE CZECH REPUBLIC AND SLOVAKIA
}

\author{
Lubica Gajanova ${ }^{1, \mathrm{a}, *}$, Margareta Nadanyiova ${ }^{1, \mathrm{~b}}$, Mihaela Musat ${ }^{2, \mathrm{c}}$ and Alexandru \\ Bogdan $^{2, \mathrm{~d}}$ \\ ${ }^{1}$ University of Zilina, The Faculty of Operation and Economics of Transport and Communications, \\ Department of Economics, Univerzitna 1, 01026 Zilina, Slovakia \\ ${ }^{2}$ Bucharest University of Economic Studies, Piata Romana 6, 010374 Bucharest, Romania \\ alubica.gajanova@fpedas.uniza.sk, ${ }^{\mathrm{b}}$ margareta.nadanyiova@fpedas.uniza.sk, \\ cmusat.mihaela11@gmail.com, dbogdan.alex25@gmail.com \\ *Corresponding author
}

Cite as: Gajanova, L., Nadanyiova, M., Musat, M., Bogdan, A. (2020). The social recruitment as a new opportunity in the Czech Republic and Slovakia. Ekonomicko-manazerske spektrum, 14(1), 65-76.

Available at: dx.doi.org/10.26552/ems.2020.1.65-76

\begin{abstract}
Social networks are phenomenon that changes the way we communicate in both personal and professional lives. Due to them, the private and work dimensions are intertwined and so no wonder that the use of social networks is also penetrated into the recruitment policy of companies. This fact is the result of a growing demand for labour force associated with a low level of unemployment. The aim of the paper is to find out whether the preferred form (traditional vs. e-recruitment) affects the success of the whole recruitment process. Based on the statistical testing using Chi-square, there is no dependence between the preferred form and its impact on the success of the recruiting process. Because social networks in their essence have a high potential to improve not only e-recruiting, but also traditional forms of recruiting, therefore, we have expanded the research in this paper by including the moderation analysis. The results confirm the importance of using social networks in both preferred forms of recruitment due to their positive impact on the success of the whole recruitment process in the Czech Republic and Slovakia.
\end{abstract}

Keywords: Social recruitment, Social networks, Moderation analysis, Czech Republic, Slovakia.

JEL Classification: M12, O35

\section{Introduction}

Personnel recruitment has been growing in importance on the labour market for years. The shortage of skilled workers is one of the greatest strategic challenges for the majority of companies, followed by remuneration and employer brand issues (Institute for Competitive Recruiting, 2012, Raven51 AG - HRM Research Institute GmbH, 2019, Tumasjan et al. 2020). Therefore, a proactive approach is required from the company's own recruiting department (Borisova et al., 2019). With the ever-increasing popularity of social networks, the possibilities of their use are expanding and penetrating into the recruitment policy of companies. (Briscariu, 2019). In addition to traditional recruitment techniques, companies around the world have demonstrably started using social networking tools to recruit employees (Muduli and Trivedi, 2020, Vetrakova et al., 2018, Bartakova et al., 2017). 
The expansion of recruiting activities on social networks is largely due to the current situation on the labour market (Sengul, 2017). The unemployment rate in the Czech Republic jumped to $3.4 \%$ in April 2020 from $3.0 \%$ in the previous month. That was the highest jobless rate since March 2018 as the number of unemployed increased by 28.4 thousand to 254.0 thousand amid the coronavirus pandemic (Trading economics, 2020a). The unemployment rate in Slovakia increased to $6.6 \%$ in April 2020, the highest since July 2017, as efforts to contain the coronavirus pandemic forced many non-essential businesses to close. The number of unemployed rose by 46.0 thousand from a year earlier to 180.8 thousand (Trading economics, 2020b). Considering the European Union as a whole, the jobless rate of the analysed countries is at the same or even lower level than the average in the European countries. The analysed countries also deal with the problem of inequality of the unemployment rate between individual the individual geographical parts (Svabova, et al.). In case of interregional comparison of the Czech Republic and Slovakia, some regions have long lower unemployment than the national average, so from a long-term perspective there is a trend where the number of vacancies exceeds the number of registered job seekers (Czech Statistical Office, 2020, Central Office of Labour, Social Affairs and Family, 2020). This fact constitutes a problem with filling vacancies, because there is a shortage of people in the labour market who are actively looking for work. The Czech Republic and Slovakia are also characterized by another factor causing problems in recruiting. The Czech as well as the Slovak labour market is threatened by the inadequate structure of the labour force, which can be perceived in two points of view. The first one is the discrepancy between the fields of study, the number of students admitted to them and the needs of the labour market. According to the Kuchař (2007), the differences in the employability of graduates of various fields on the labour market will deepen further. Since the early 1990s, economic fields of study have been significantly preferred. However, their graduates have an increasingly difficult situation finding employment in the labour market (Kaczor, 2013). The graduates of some humanity fields of study are in a similar situation. This discrepancy is reflected in changing personnel strategies and changes in the ways of finding new sources of labour, for example through social networks. The second point of the view is the inadequate level of university graduates. Most secondary and higher education institutions have set their capacities at a time when strong population grades were entering them and there were relatively enough students in the education market (Kaczor, 2013, s. 39). Currently, population-poor grades are entering universities and they are reducing selection criteria to fill the capacity. As a result, the quality of graduates decreases and the university diploma ceases to be proof for companies of a certain professional, intellectual and personal level of its holder (Kaczor, 2013, s. 39).

Social networks are a place where it is possible to find out more information about candidates, thereby the topicality of the article is more than obvious. However, the use of erecruiting cannot be interpreted as a substitute for traditional forms of recruitment. World surveys (Rabe, 2020, Mishra and Cuman, 2019, Awdu et al., 2019, Social Talent, 2016, Sekaquaptewa et al., 2019, Bazan et al., 2019) and surveys conducted in the countries studied (Hlavačková, 2018, Grant Thornton, 2019) clearly confirm the parallel existence of the application of tools using and not using the Internet. However, these surveys were performed only to analyse the current state of the various recruitment channels. They, apart from the Mazarean (2020) and Golovko and Schumann (2019) research, did not deal with the overall success of the recruitment process in the surveyed companies, which represents the research gap. Therefore, the aim of the paper is to find out whether the preferred form (traditional vs. erecruitment) has an impact on the success of the whole recruitment process. 


\section{Literature Review}

Social recruitment is the process of recruiting candidates by using data from social networks for the targeted placement of the advertising messages by employers and recruiters who are oriented towards the interests of the target persons - potential candidates (Dannhäuser, 2015). First of all, it is important to define and differentiate terms in the area of recruiting. Instead of social recruiting, the term e-recruiting is often incorrectly used for activities in the online personnel search (Dannhäuser, 2015). E-recruitment, also known as online recruitment, refers to the use of web-based technology for the various processes of attracting, assessing, selecting, recruiting and on boarding job candidates (Mishra, 2019, Raghavendra, 2018, Tyagi, 2016). Social networks are one of the platforms for e-recruiting but may also be applicable to traditional one (de Juana-Espinosa, 2011).

Social networks are gaining more and more attention in the field of recruitment. They play an important role in the recruitment strategy of companies (Alleyene, 2011). About $40 \%$ of recruiters actively use social networks for recruitment and $46 \%$ of recruiters planned to start using them in the coming year (Jobvite, 2015). The use of social networks for recruiting purposes is directly proportional to the size of the companies (Forum for In-house Recruitment Managers, 2019). Around $72 \%$ of companies already use social networks to recruit specialists and managers (Dannhäuser, 2015). Other statistics, e.g. according to Jobvite (2016) show that $48 \%$ of the candidates surveyed used social networks, especially Facebook, to find their last job. According to Talent Works (2017), 83\% of candidates are active on Facebook, $40 \%$ on Twitter, and $30 \%$ on LinkedIn. However, Facebook is used by recruiters only in $55 \%$ of cases, most recruiters still occur primarily on LinkedIn, up to 87\% (Talent Works, 2017). The above statistics show a discrepancy between the use of the social networks by candidates and recruiters. Instagram has not yet been mentioned in the above list of social networks in recruitment, because this network is used mainly by younger generation (Jobvite, 2017). Another survey showed a very relevant differences in the rate of usage for each of these networks in three different geographical regions of the study. While $93 \%$ of the North American human resources professionals and hiring managers surveyed said they used LinkedIn for recruitment purposes, this figure went down to $42 \%$ and $32 \%$ for the human resources professionals and hiring managers located in Europe and Asia-Pacific. The North American human resources professionals use Facebook in $34 \%$. In contrast, the European and Asia Pacific hiring managers use Facebook much more often - 62\% and 75\%. In North America (18\%) and in Europe (35\%) Twitter is the least used social network in recruiting (Alleyne, 2011). Within the available information regarding data describing the analysed phenomenon in the Czech Republic and Slovakia, much higher percentage data on the use of social networks by companies are presented, but this is due to the fact that the data describe e-recruitment, not only social recruitment itself (Kozmová, 2018).

Social networks have a high potential to improve not only social recruiting, but also traditional forms of recruiting through screening. Screening can be defined as finding additional information about a candidate that is not included in his/her Curriculum Vitae. Screening of candidates on social networks allows human resource professionals access to personal information about the candidate, often information of a private nature that has little to do with the performance of work (Caers and Castelyns, 2011). This information is also obtained without the candidate's consent (Jones et al., 2012). Human resources professionals believe that on social networks the candidate has no reason to style himself/herself in the role of a desirable job seeker. In this way, they hope to obtain more accurate information about the candidate's personality. However, on social networks, the candidate also stylizes, only for other reasons. For example, he/she tries to impress his/her friends. Thus, the use of social networks in 
screening may have the opposite effect than that for which it is used. Rather than finding more accurate information about the candidate, it can lead to prejudice and discrimination against the candidate (Davidson et al., 2011, Jeske and Shultz, 2016). However, most authors report the positive impact of screening, but also agree that the use of social networks in screening remains an unresolved area with a number of potential legal implications. (Davidson et al., 2011, Jones et al., 2012, Blacksmith and Poeppelman, 2014).

\section{Methodology}

The aim of the paper is to find out whether the preferred form (traditional vs. e-recruitment) has an impact on the success of the whole recruitment process. The causal relational hypothesis was established to answer the research statement as follows. There is no statistically significant relationship between the preferred form of recruitment and its impact on the whole recruitment process.

By testing causal hypotheses, researchers not only test their hypotheses or theories about the relevant phenomenon of science, but also find answers to practical questions about whether or not the intervention has the expected effect. However, researchers go beyond the simple reason for the cause and effect of a relationship and try to understand what bridges causality (Rose et al, 2004, Amery and Zumbo, 2008). A number of authors (Liu et al., 2020, Ma et al., 2020, Zhao et al., 2020) pay close attention to the moderating variables in research. Moderator is a qualitative or quantitative variable that affects the direction or intensity of the relation of a predictive variable (independent) and another dependent one (MacKinnon, 2008). Specifically, in the analysis, the moderation corresponds to individual differences or situational conditions, which change the relation initially proposed between two other variables (Edwards \& Lambert, 2007). The relation can be specified according to the Figure 1.

Figure 1: Conceptual Model of Simple Moderation

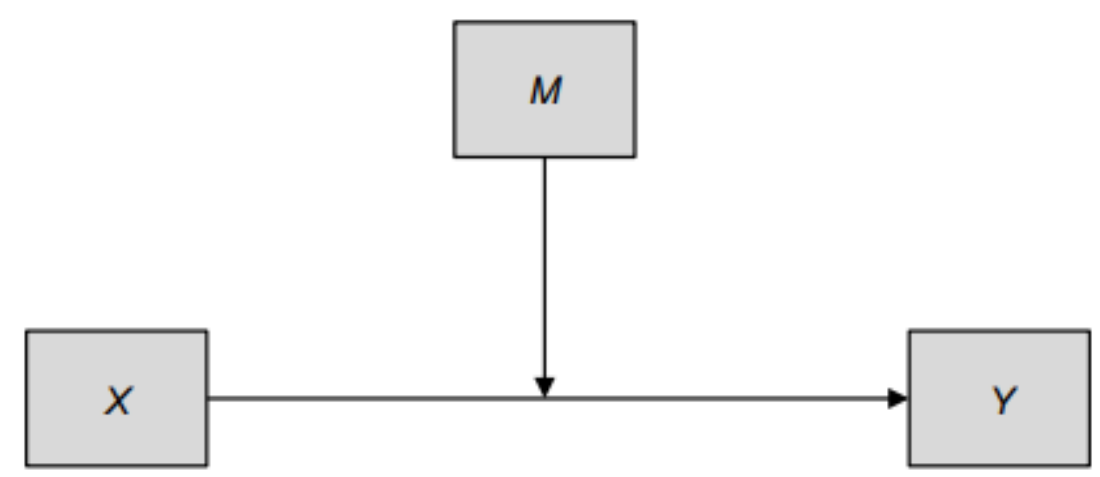

Source: Hayes (2013)

In a formal statistical model of this nature, the relation involves independent variable, moderator and dependent variable, according to the following equation

$$
Y=i+c_{1} X+c_{2} M+c_{3} X m+c_{y}
$$

Where $\mathrm{i}$ is the regression intercept, eY is the error when estimating $\mathrm{Y}$ and $\mathrm{c} 1, \mathrm{c} 2$, and $\mathrm{c} 3$ correspond to the main effect of the independent variable $\mathrm{X}$ on $\mathrm{Y}$, main effect of $\mathrm{M}$ on $\mathrm{Y}$, and interaction effect between $\mathrm{X}$ and $\mathrm{M}$ on $\mathrm{Y}$, respectively. This last one is used to check the moderation effect of $\mathrm{M}$ on the relation between $\mathrm{X}$ and $\mathrm{Y}$. The proposed model can be used with independent and moderating variables and qualitative and non-qualitative variables (Prado et al., 2014). 
In our research and in accordance with the hypothesis between the independent variable $X$ (preferred form of recruitment) and the dependent variable $\mathrm{Y}$ (the success of the whole recruitment process), the variable $M$ will be the use of social networks in the preferred form of recruitment. This is based on the literature review according to which it is possible to state that social networks can affect not only the e-recruiting but also the traditional one. Respondents could rate the success of the whole recruitment process with a 5-point Likert scale, where 1 was the lowest level (very poor) and 5 was the highest one (excellent). Respondents had the opportunity to choose from the answers always, occasionally and never in the answering of the question about the frequency of using social networks within the preferred form of recruitment.

Statistical hypothesis testing as well as moderation was performed on the whole sample, which consisted of Czech and Slovak human resources professionals and hiring managers. An index, was used to observe discrepancies between the countries studied. It is an expression that measures each value based on its relative significance to the other values in the table. The index indicates the relative significance of a particular value in a pivot table cell (nij) relative to other cells and the total number of responses (n). The index calculates the weigh that an item contributes to the overall total. The index compares each value to its row total, its column total, and the overall total, using a weighted average (Dalgleish, 2007). Put simply, the index expresses the degree of protrusion or backwardness in a given sample. That is, how much the index for a particular cell loses to or exceeds number 1 . If all values in the pivot table were equal, each value would have an index of 1 . If an index is less than 1, itis of less importance in its row and column. If an index is greater than 1 , it is of greater importance in its row and column (Dalgleish, 2008). The formula for calculating the index is as follows.

$$
\text { Index }=\frac{n i j \times n}{n . j \times n i}
$$

where $\quad n i j$ is frequencies in the pivot table;

$n$ is sum of all frequencies in the pivot table;

$n . j$ is sum of frequencies in pivot table rows;

ni. is sum of frequencies in pivot table columns (Dalgleish, 2007).

The survey was conducted in May 2020 by means of the CAWI method on a representative sample of Czech and Slovak recruiters. The CAWI method (Computer Assisted Web Interviewing) is interviewing using websites, portals and also emails. The size of the representative sample was determined by the following equation.

$$
n \geq \frac{\mathrm{t} \alpha^{2} \times \mathrm{p} \times(1-\mathrm{p})}{d^{2}}
$$

Where $\quad n$ is the minimum number of respondents;

t $\alpha$ is the critical value of the normal distribution at significance level $\alpha=0.05$;

$\mathrm{p}$ is the likely sample proportion, expressed as a decimal;

$d$ is the confidence interval, expressed as a decimal (Moravcikova et al., 2017).

The confidence level was set at $95 \%$. The critical value of the normal distribution at confidence level $\alpha=0.05$ was 1.96 . This is based on the fact, that $\%$ of the area of the normal distribution is within 1.96 standard deviations of the mean. For those cases where the likely sample proportion was not known, $\mathrm{p}$ was set at $50 \%$. The confidence interval was set at $8 \%$. In order to conduct a survey of the impact of preferred form of recruitment on the success of the whole recruitment process also with the moderation, it is necessary to provide a sample of at least 150 respondents. 


\section{Results}

The role of statistical inference is to decide on the basis of information on the available choices whether to accept or reject certain hypotheses with respect to the basic sample set. In order to do so, we proceeded in accordance with the methodology of statistical hypothesis testing, which consists of the following steps: Formulation of the null hypothesis (H0); Formulation of the alternative hypothesis (H1); Determination of the level of significance $(\alpha)$; Calculation of test statistics and probability; and Conclusion (Rimarčík, 2007). To calculate the test statistics for the hypothesis, IBM SPSS Statistics software was used (Table 1). Because the primary data in this research is of a nominal nature as well, the test statistic is a Chi-square test of independence.

Table 1: Chi-Square Test

\begin{tabular}{lccc}
\hline & Value & df & Asymptotic Significance (2-sided) \\
\hline Pearson Chi-Square & $8.445^{\mathrm{a}}$ & 4 & $\mathbf{0 . 0 7 7}$ \\
Likelihood Ratio & 8.685 & 4 & 0.069 \\
Linear-by-Linear Association & 5.069 & 1 & 0.024 \\
N of Valid Cases & 150 & & \\
\hline
\end{tabular}

a. 0 cells $(0,0 \%)$ have expected count less than 5 . The minimum expected count is 5.44 .

Source: authors according to SPSS

A significance level was determined at 0.05 and corresponded to a $95 \%$ confidence interval. Based on the comparison of the significance level with the P-value (Asymptotic Significance), the null hypothesis was confirmed, so there is no statistical dependence between the variables examined (the preferred form of recruitment and the success of the whole recruitment process).

Despite the non-confirmation of the dependence between the examined variables, we can find out the internal structure of the answers in order to determinate the differences between the respondents from individual countries. Table 2 provides an overview of the number of responses $(\mathrm{N})$, percentage $(\%)$ and calculated index of responses in a specific target group (Czech and Slovak recruiters) for a particular item (preferred form of recruitment).

Table 2: Pivot table of responses (Country/Preferred form)

\begin{tabular}{lcccccc}
\hline \multirow{2}{*}{ Country/Preferred form } & \multicolumn{3}{c}{ Traditional recruitment } & \multicolumn{3}{c}{ E-recruitment } \\
& $\mathrm{N}$ & $\%$ & $\mathrm{Index}$ & $\mathrm{N}$ & $\%$ & Index \\
\hline Czech republic & 25 & 39.68 & 0.8754 & 38 & 60.32 & $\mathbf{1 . 1 0 3 4}$ \\
Slovakia & 43 & 49.43 & $\mathbf{1 . 0 9 0 3}$ & 44 & 50.57 & 0.9251 \\
\hline
\end{tabular}

Source: authors

The use of e-recruitment predominates among Czech recruiters according to the results of the internal structure, in contrast to the Slovak ones, which prefer the traditional forms of recruitment. Table 3 provides an overview of the number of responses $(\mathrm{N})$, percentage $(\%)$ and calculated index of responses in a specific target group (Czech and Slovak recruiters) for a particular item (success of the whole recruitment process).

The results of the evaluation of the success of the entire recruitment process do not show a clear difference in the comparison of the examined countries. The answers of Czech recruiters are unbalanced as data with a value greater than 1 are significant, i.e. very poor, above average and excellent. The answers of Slovak recruiters were more consistent, they leaned towards neutral respectively a very positive success. 
Table 3: Pivot table of responses (Country/ Success of the whole recruitment process)

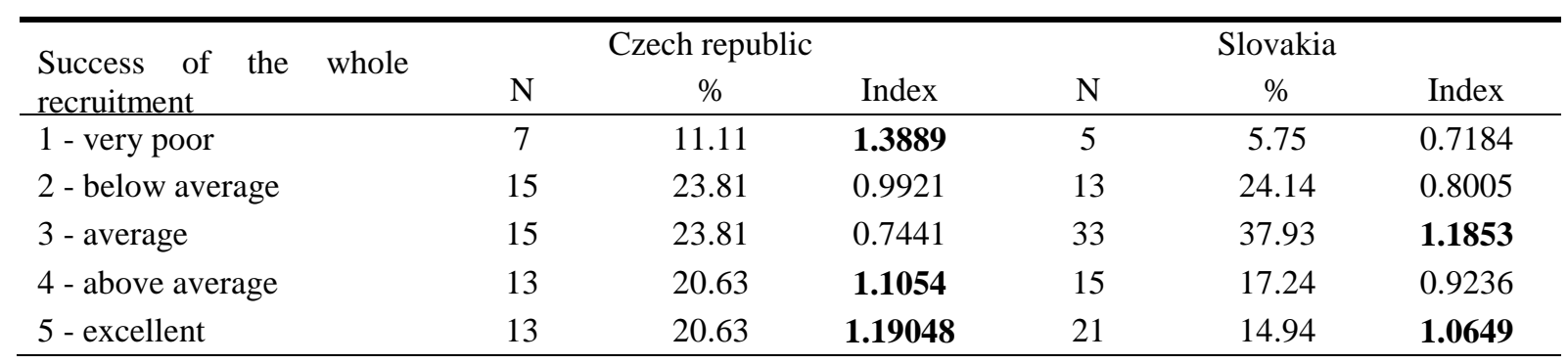

Source: authors

The results of the evaluation of the success of the entire recruitment process do not show a clear difference in the comparison of the examined countries. The answers of Czech recruiters are unbalanced as data with a value greater than 1 are significant, i.e. very poor, above average and excellent. The answers of Slovak recruiters were more consistent, they leaned towards neutral respectively a very positive success. Table 4 provides an overview of the number of responses $(\mathrm{N})$, percentage $(\%)$ and calculated index of responses in a specific target group (Czech and Slovak recruiters) for a particular item (Using the Social Networks in the preferred form of recruitment).

Table 4: Pivot table of responses (Country/Using the Social Networks)

\begin{tabular}{lcccccc}
\hline Using the & Social & \multicolumn{3}{c}{ Czech republic } & \multicolumn{3}{c}{ Slovakia } \\
Networks/Country & $\mathrm{N}$ & $\%$ & Index & $\mathrm{N}$ & $\%$ & Index \\
\hline 1 - always & 19 & 30.16 & $\mathbf{1 . 0 7 7 1}$ & 23 & 26.44 & 0.9441 \\
2 - occasionally & 26 & 41.27 & $\mathbf{1 . 0 1 4 7}$ & 35 & 40.23 & 0.9893 \\
3 - never & 18 & 28.57 & 0.9119 & 29 & 33.33 & $\mathbf{1 . 0 6 3 8}$ \\
\hline
\end{tabular}

Source: authors

According to the internal structure of responses based on the country and using the Social Networks in the preferred form of recruitment, we can clearly determine that Czech recruiters, unlike Slovak recruiters, clearly use social networks in the preferred form of recruitment.

Based on the summary of data from Tables 2 to 4, it is not possible to determine whether the social networks themselves have an impact on the success of the overall recruitment process. For this reason, it is justified to examine the effect of social networks on the success of recruitment using moderation analysis. IBM SPSS statistical software was used to test moderation effect by PROCESS, a tool developed for conditional process modelling in SPSS. In analyse presented below, the significance of the moderating effect was obtained by computing $95 \%$ confidence intervals using 5000 bootstrap samples. The calculation is presented in Figure 2. 
Model: 1

Figure 2: Calculation of Moderation

$Y$ : Success of whole process

$\mathrm{X}$ : Preferred form

W: Social Networks

Sample

Size: 150

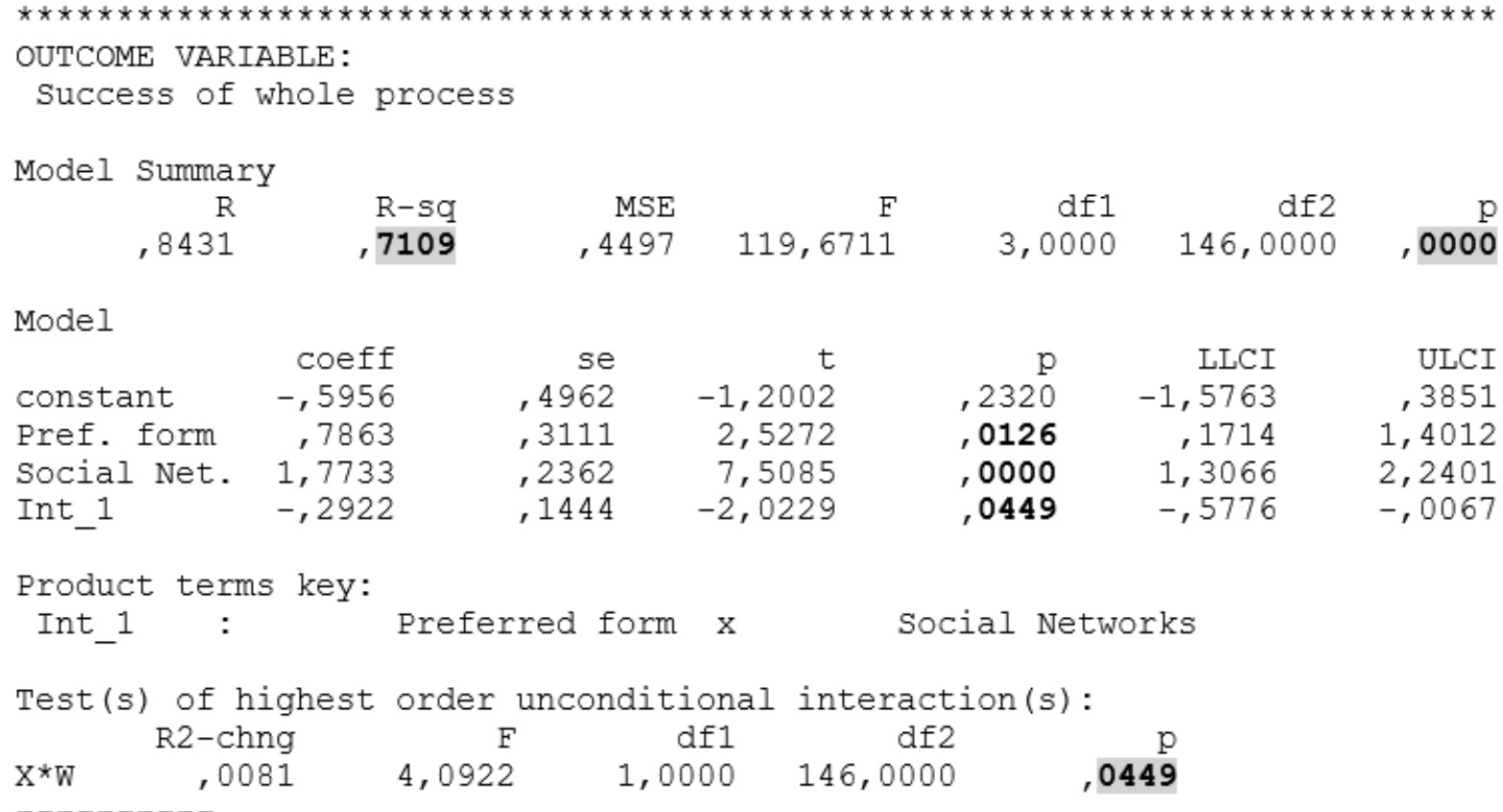

Source: authors according to SPSS

The results of the analysis begin with summary of the chosen model (Model 1 - simple moderation model), the established variables (independent X, dependent $\mathrm{Y}$ and moderator $\mathrm{W}$ ) and the sample size. Various indicators of calculation are presented in the Model Summary. The R-sq and p-value indicators, which present the high quality of the regression model, have the greatest explanatory power. The Model section presents the results of performing of three different linear regression analyses. The first one expresses the influence of the independent variable $(\mathrm{X})$ on the dependent variable $(\mathrm{Y})$. The second linear regression demonstrates the effect of the moderating variable (W) on the dependent variable (Y). The third and most important interaction (Int_1) is automatically generated based on the effect between the independent variable and the moderating variable $(\mathrm{XW})$ on the dependent variable $(\mathrm{Y})$. At the significance level $\alpha=0.05$, social networks represent a positive moderator of the relationship between the variables $\mathrm{X}$ and $\mathrm{Y}$. This clearly confirmed the importance of using social networks in both preferred forms of recruitment due to their positive impact on the success of the whole recruitment process in the Czech Republic and Slovakia.

\section{Discussion}

Although the literature demonstrates various forms and channels in recruitment process in the companies, these claims are not well documented from the point of view about their impact on the welfare of the whole recruitment process. The aim of the paper was to find out whether the preferred form (traditional vs. e-recruitment) has an impact on the success of the whole 
recruitment process. The dependence between the examined variables was not confirmed. From which we can deduce that the parallel use of traditional forms of recruitment together with erecruitment is justified in the Czech Republic and Slovakia and this situation correlates with research presenting the coexistence of the application of tools using and not using the Internet. (Rabe, 2020, Mishra and Cuman, 2019, Awdu et al., 2019, Social Talent, 2016, Sekaquaptewa et al., 2019, Bazan et al., 2019, Hlavačková, 2018, Grant Thornton, 2019). The aim of the paper was also to analyse the current state and opinion of human resources managers in the field of recruitment in the Czech Republic and Slovakia, based on the fact that the phenomenon is addressed by a minimum number of research in the monitored area and their results cannot be compared due to different approaches in acquiring of data.

Unambiguous results of comparison based on internal structure of answers show that the use of e-recruitment predominates among Czech recruiters, in contrast to the Slovak ones, which prefers the traditional forms of recruitment such as internal sourcing, recommendations of current employees, contracting employees already during the study at vocational schools and universities (Giannantonio et al., 2019, Awdu et al., 2019, Sekaquaptewa, 2019). According to the internal structure of responses based on the country and using the social networks in the preferred form of recruitment, we can clearly determine that Czech recruiters, unlike Slovak recruiters, clearly use social networks in the preferred form of recruitment. In this way, Slovak recruiters showed distrust of social networks and thus manifested themselves as human resources managers, who again and again underestimate the complexity and possibilities of recruitment through social media, and therefore do not deal with this entity intensively enough. (Dannhäuser, 2015). Whereas foreign research presents social networks as a common tool for finding candidates (Keleher, 2020, Jobvite, 2016). The results of the use of social networks in the analysed countries point to the situation that up to one third of the respondents do not use social recruiting at all. And so our assumption was confirmed that the researches in the Czech republic and Slovakia erroneously state high values due to the fact that the data describe erecruitment, not only social recruitment itself. (Kozmová, 2018). The unambiguity of the answers among the representatives of the analysed countries was no longer in the evaluation of the impact of the preferred form of recruitment on the overall success of it. While Czech respondents provided answers at both limits of the assessment scale and thus demonstrated inconsistencies of opinion, Slovak recruiters evaluated the influence of the preferred form of recruitment on its success, especially in the neutral or excellent level. From the information obtained in this way it is not possible to deduce the very effect of social networks on the success of the recruitment process and because social networks in their essence have a high potential to improve not only e-recruiting, but also traditional forms of recruitment, so we have expanded the research in this paper by including the moderation analysis, which clearly confirmed the positive impact of using social networks on the whole recruitment process in the Czech Republic and Slovakia. So this paper strengthens the justification for the use of social recruitment and thus there is a consensus with other sources that have recently identified an enormous increase in the use of social networking tools to recruit the employees (Briscariu, 2019, Muduli and Trivedi, 2020, Vetrakova et al., 2018, Bartakova et al., 2017).

\section{Conclusion}

Demographic change, low unemployment, globalization and increased competition make it difficult for businesses to retain and hire suitable employees. For these reasons, finding potential candidates on the Internet is becoming increasingly important for recruitment, and in recent years, in this context, much attention has also been paid to social networks. Under the 
current conditions, the use of exclusively traditional means of recruiting and reaching employees is insufficient. Today, it is no longer possible to rely on only one source of candidates, but it is necessary to engage and learn to use new resources, the most accessible of which are social networks. Today, social networks are an important source of information about potential job seekers and a place to look for suitable job candidates. Our study clearly confirmed the importance of using social networks in both preferred forms of recruitment due to their positive impact on the success of the whole recruitment process in the Czech Republic and Slovakia. In our paper, we did not deal with the forecast of the development of the unemployment rate due to COVID-19 disease, which may represent a limit of research. However, Nassim Nicholas Taleb, an expert in the field of probability, does not consider the COVID-19 disease as a black swan but as a somehow preventable event. In addition, in the countries studied, the problems with a shortage of skilled workers are not only due to low unemployment rate. The questionnaire survey was conducted only in the presence of a geographically limited population. This was done to find out the parochialism of Czechs and Slovaks. From a certain point of view, it may represent another limitation to this paper. It can be removed if the research results will be subsequently verified and compared in an international environment. If these barriers were removed, more accurate results could be achieved.

\section{References}

Allyene, S. (2011) Findig the Right Candidate. Black Enterprise, 42(5), pp. 44-52.

Amery, D., and Zumbo, B. D. (2008). Understanding and using mediators and moderators. Social Indicators Research Series, 87, pp. 367-392, doi: 10.1007/s11205-007-9143-1.

Awudu, I., Kuppusamy, S., Norbis, M. and O'Connor, M. (2019). Recruitment strategies in a university institution: a theoretical cost minimization approach. Cogent Economics \& Finance, 7(1), 1607050. doi: 10.1080/23322039.2019.1607050

Bartakova, G. P., Gubiniova, K. Brtkova, J. and Hitka, M. (2017). Actual trends in the recruitment process at small and medium-sized enterprises with the use of social networking. Economic Annals-XXI, 164(3-4), pp. 80-84. doi: 10.21003/ea.V164-18.

Bazan, V., Hermoso, R. and Escario, I. (2019). E-recruitment in Spain: Evolution and use of ICTs to attract candidates. Acciones e investigaciones sociales, 39, 201-222.doi: 10.26754/ojs_ais/ais.2019393238.

Blacksmith, N. and Poeppelman, T. (2014). Three ways social media and technology have changed recruitment. The Industrial-Organizational Psychologist, 52(1), pp. 114-121.

Borisova, A., Rakhimberdinova, M., Madiyarova, E., Riazantseva, I. and Mikidenko, N. (2019). Staffing search and recruitment of personnel on the basis of artificial intelligence. Entrepreneurship and Sustainability Issues, 6(4), pp. 2456-2469. doi: 10.9770/jesi.2019.6.4(66).

Briscariu, R. (2019). The use of social networks sites in the recruitment process. Management Research and Practice, 11(4), pp. 5-10.

Caers, R. and Castelyns, V. (2011). LinkedIn and Facebook in Belgium: The influences and biases of social network sites in recruitment and selection procedures. Social Science Computer Review, 29(4), pp. 437-448. doi: 10.1177/0894439310386567.

Central Office of Labour, Social Affairs and Family (2020). Nezamestnanost' - mesačné štatistiky. [Online]. Available at: https://www.upsvr.gov.sk/statistiky/nezamestnanost-mesacnestatistiky/2020.html?page_id=971502

Czech Statistical Office (2020). V dubnu vzrostla v Králové hradeckém kraji míra nezaměstnanosti i počet uchazečů. [Online]. Available at: https://www.kurzy.cz/zpravy/544381-v-dubnu-vzrostla-vkralovehradeckem-kraji-mira-nezamestnanosti-i-pocet-uchazecu/.

Dalgleish, D. (2007). Beginning Pivot Tables in Excel 2007, Apress.

Dalgleish, D. (2008). Excel 2007 PivotTables Recipes: A Problem-Solution Approach, Apress.

Dannhäuser, R. (2015). Praxishandbuch Social Media Recruiting: Experten Know-How/Praxistipps/ Rechtshinweise, Wiesbaden: Springer Gabler. 
Davison, H. K., Maraist, C. and Bing, M. N. (2011). Friend or foe? The promise and pitfalls of using social networking sites for hr decisions. Journal of Business \& Psychology, 26(2), 153-159. doi: 10.1007/s10869011-9215-8.

de Juana-Espinosa, D. (2011). Human resource management in the digital economy: Creating synergy between competency models and information, IGI Global.

Edwards, J. R. and Lambert, L. S. (2007). Methods for integrating moderation and mediation: A general analytical framework using moderated path analysis. Psychological Methods, 12(1), 1-22. doi: 10.1037/1082989X.12.1.1.

Forum for In-house Recruitment Managers (2019). Annual membership survey. [Online]. Available at: https://thefirm-network.com/wp-content/uploads/dlm_uploads/2018/01/The-FIRM-Annual-MembershipSurvey-2017-v2-LO-003.pdf.

Giannantonio, C. M., Hurley-Hanson, A. E., Segrest, S. L., Perrewe, P. L. and Ferris, G. R. (2019). Effects of recruiter friendliness and job attribute information on recruitment outcomes. Personnel Review, 48(6), pp. 1494-1506. doi: 10.1108/PR-01-2018-0037

Golovko, D. and Schumann, J. H. (2019). Influence of company Facebook activities on recruitment success. Journal of Business Research, 104, pp. 161-169. doi: 10.1016/j.jbusres.2019.06.029

Grant Thornton (2019). Sociální sítě v HR marketing a recruitment. [Online]. Available at: http://socialnisitevhr.cz/wp-content/uploads/Grant-Thornton_Socialni-site-v-HR_2019.pdf

Hayes, A. F. (2013). Introduction to mediation, moderation, and conditional process analysis, New York: The Guilford Press.

Hlaváčková, Z. (2018). Nájst' zamestnancov je čoraz náročnejšie. [Online]. Available at: https://uzitocna.pravda.sk/praca-a-kariera/clanok/469398-najst-zamestnancov-je-coraz-narocnejsie/

Institute for Competitive Recruiting (2012). DACH Recruiting Report. [Online]. Available at: https://competitiverecruiting.de/DACHRecruitingReport2012.html.

Jeske, D. and Shultz, K. S. (2016). Using social media content for screening in recruitment and selection: pros and cons. Work employment and society, 30(3), 535-546. doi: 10.1177/0950017015613746.

Jobvite (2015). Job Seeker Nation Study 2015. [Online]. Available at: https://www.jobvite.com/2015-job-seekernation-study/.

Jobvite (2016). Job Seeker Nation Study 2016. [Online]. Available at: https://www.jobvite.com/jobvite-news-andreports/2016-job-seeker-nation-study-reports-on-the-future-of-work/.

Jobvite (2017). Job Seeker Nation Study 2017. [Online]. Available at: https://www.jobvite.com/jobvite-news-andreports/2017-job-seeker-nation-survey-finding-fault-lines-american-workforce/.

Jones, M., Schuckman, A. and Watson, K. (2012). The Ethics of Pre-Employment screening Through the Use of the Internet. [Online]. Available at: http://www.ethicapublishing.com/ethical/3CH4.pdf.

Kaczor, P. (2013). Trh práce, pracovní migrace a politika zaměstnanosti ČR po roce 2011, Prague: Oeconomica.

Keleher, M. (2020). Social Recruiting: Survey, Statistics and Infographics. [Online]. Available at: https://www.agencycentral.co.uk/recruitment-spotlight/social-recruiting-survey-stats-and-infographics/.

Kormová, M. (2018). Co je social recruiting. [Online]. Available at: http://socialnisitevhr.cz/co-je-socialrecruiting/.

Kuchař, P. (2007). Trh práce: sociologická analýza, Prague: Karolinum,

Liu, W. L., He, C. Q., Jiang, Y., R. R. and Zhai, X. S. (2020). Effect of gig workers' psychological contract fulfillment on their task performance in a sharing economy-a perspective from the mediation of organizational identification and the moderation of length of service. International Journal of Environmental research and public health, 17(7), 2208. doi: 10.3390/ijerph17072208.

Ma, F., Guo, D., Yuen, K. F., Sun, Q. P., Ren, F. X., Xu, X. B. and Zhao, C. Y. (2020). The influence of continuous improvement of public car-sharing platforms on passenger loyalty: a mediation and moderation analysis. International Journal of Environmental Research and Public Health, 17(8), pp. 2756. doi: 10.3390/ijerph17082756.

Mackinnon, D. P. (2008). Introduction to statistical mediation analysis, Mahwah, NJ: Erlbaum.

Mazareanu, E. (2020). Effectiveness of recruitment channels worldwide 2018. [Online]. Available at: https://www.statista.com/statistics/881148/effectiveness-of-recruitment-channels-worldwide./

Mishra, S. and Kumar, S. P. (2019). E-recruitment and training comprehensiveness: untapped antecedents of employer branding. Industrial and commercial training, 51(2), 125-136. doi: 10.1108/ICT-12-2017-0106.

Moravcikova, D., Krizanova, A., Kliestikova, J., Rypakova, M. (2017). Green marketing as the source of the competitive advantage of the business. Sustainability, 9(12), pp. 2218. doi: 10.3390/su9122218.

Muduli, A. and Trivedi, J. J. (2020). Social media recruitment: the role of credibility and satisfaction. Evidencebased HRM - a global forum for empirical scholarship, 8(2), pp. 237-251. doi: 10.1108/EBHRM-08-20190069. 
Prado, P. H. M., Korelo, J. C. and da Silva, D. M. L. (2014). Mediation, moderation and conditional process analysis. REMark - Revista Brasileira de Marketing, 13(4), pp. 4-24. doi: 10.5585/remark.v13i4.2739.

Rabe, L. (2020). Recruiting-Kanäle nach Anteil der Neueinstellungen bis 2019. [Online]. Available at: https://de.statista.com/statistik/daten/studie/150258/umfrage/anteil-der-recruiting-kanaele-an-denneueinstellungen-von-unternehmen./

Raghavendra, B., Priyanka, C. and Chaithanya, G. (2018). A study on E recruitment. International Journal of Advance Research in Science and Engineering, 7(3), pp. 843-852.

Raven51 AG - HRM Research Institute GmbH (2017). Recruiting intelligence guide. [Online]. Available at: .https://www.personal-manager.at/fileadmin/PM/epaper/RIG_Online.pdf

Rimarčík, M., 2007. Štatistika pre prax, Marián Rimarčík.

Rose, B. M., Holmbeck, G. N., Coakley, R. M. and Franks, E. A. (2004). Mediator and Moderator Effects in Developmental and Behavioral Pediatric Research. Developmental and Behavioral Pediatrics, 25(1), pp. 5867. doi: 10.1097/00004703-200402000-00013.

Sekaquaptewa, D., Takahashi, K., Malley, J., Herzog, K. and Bliss, S. (2019). An evidence-based faculty recruitment workshop influences departmental hiring practice perceptions among university faculty. Equality Diversity and Inclusion, 38(2), pp. 188-210. doi: 10.1108/EDI-11-2018-0215.

Sengul, G. (2017). Effect of labor market policies on unemployment when firms adapt their recruitment strategy. Economic Modelling, 60, pp. 169-179. doi: 10.1016/j.econmod.2016.09.012.

Social Talent (2016). Global Recruiting Survey. [Online]. Available at: https://www.socialtalent.com/wpcontent/uploads/2016/06/Global-Recruiting-Survey-2016.pdf.

Svabova, L, Durica, M., Kramarova, K., Valaskova, K. and Janoskova, K. (2019). Employability and sustainability of young graduates in the Slovak labour market: Counterfactual approach. Sustainability, 11(16), pp.4462. doi: $10.3390 / \mathrm{su} 11164462$.

Talent Works (2017). 8 Social Media Statistics You Need To Know If You Are In Recruitment. [Online]. Available at: https://www.talent-works.com/2017/09/27/social-media-recruitment/.

Trading economics (2020a). Czech Republic Unemployment Rate. [Online]. Available at: https://tradingeconomics.com/czech-republic/unemployment-rate.

Trading economics (2020b). Slovakia Unemployment Rate. [Online]. Available at: https://tradingeconomics.com/slovakia/unemployment-rate.

Tumasjan, A., Kunze, F., Bruch, H. and Welpe, I. M. (2020). Linking employer branding orientation and firm performance: Testing a dual mediation route of recruitment efficiency and positive affective climate. Human Resource Management, 59(1), pp. 83-99. doi: 10.1002/hrm.21980.

Tyagi, A. (2016). Impact of E-recruitment on Human Resource, Horizon Books.

Vetrakova, M., Hitka, M., Potkany, M., Lorincova, S. and Smerek, L. (2018). Corporate sustainability in the process of employee recruitment through social networks in conditions of slovak small and medium enterprises. Sustainability 10(5), pp. 1670. doi: 10.3390/su10051670.

Zhao, X., Wang, J. and Shi, C. (2020). The influence of mental resilience on the positive coping style of air force soldiers: A moderation-mediation model. Frontiers in Psychology, 11, pp. 550. doi: 10.3389/fpsyg.2020.00550 